\title{
Application of Selected Inoculant Producing Antifungal and Fibrinolytic Substances on Rye Silage with Different Wilting Time
}

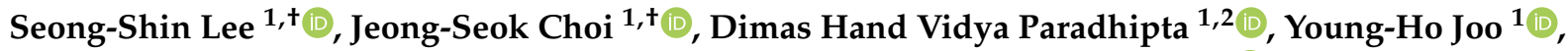 \\ Hyuk-Jun Lee ${ }^{1}$, Hyeon-Tak Noh ${ }^{1}$, Dong-Hyeon Kim $^{3}$ and Sam-Churl Kim ${ }^{1, * D}$ \\ 1 Division of Applied Life Science (BK21Four, Institute of Agriculture \& Life Science), \\ Gyeongsang National University, Jinju 52828, Korea; seongshin73@gmail.com (S.-S.L.); \\ x47677104@gmail.com (J.-S.C.); dimazhand@gmail.com (D.H.V.P.); wn5886@gmail.com (Y.-H.J.); \\ hyukjun0209@gmail.com (H.-J.L.); nht1647@gmail.com (H.-T.N.) \\ 2 Faculty of Animal Science, Universitas Gadjah Mada, Yogyakarta 55281, Indonesia \\ 3 Dairy Science Division, National Institute of Animal Science, Cheonan 31000, Korea; kimdh3465@gmail.com \\ * Correspondence: kimsc@gnu.ac.kr; Tel.: +82-557721947; Fax: +82-557721949 \\ + These authors contributed equally to this work.
}

\section{check for}

updates

Citation: Lee, S.-S.; Choi, J.-S.; Paradhipta, D.H.V.; Joo, Y.-H.; Lee, H.-J.; Noh, H.-T.; Kim, D.-H.; Kim, S.-C. Application of Selected Inoculant Producing Antifungal and Fibrinolytic Substances on Rye Silage with Different Wilting Time. Processes 2021, 9, 879. https://doi.org/ $10.3390 /$ pr9050879

Academic Editors: Aydin Berenjian and Ehsan Mahdinia

Received: 6 May 2021

Accepted: 14 May 2021

Published: 17 May 2021

Publisher's Note: MDPI stays neutral with regard to jurisdictional claims in published maps and institutional affiliations.

Copyright: (c) 2021 by the authors. Licensee MDPI, Basel, Switzerland This article is an open access article distributed under the terms and conditions of the Creative Commons Attribution (CC BY) license (https:// creativecommons.org/licenses/by/ $4.0 /)$
Abstract: This research was conducted to determine the effects of selected inoculant on the silage with different wilting times. The ryes were unwilted or wilted for $12 \mathrm{~h}$. Each rye forage was ensiled for $100 \mathrm{~d}$ in quadruplicate with commercial inoculant (Lactobacillus plantarum sp.; LPT) or selected inoculant (Lactobacillus brevis 100D8 and Leuconostoc holzapfelii 5H4 at 1:1 ratio; MIX). In vitro dry matter digestibility and in vitro neutral detergent fiber digestibility were highest in the unwilted MIX silages $(p<0.05)$, and the concentration of ruminal acetate was increased in MIX silages $(p<0.001$; $61.4 \%$ vs. $60.3 \%$ ) by the increase of neutral detergent fiber digestibility. The concentration of ruminal ammonia-N was increased in wilted silages ( $p<0.001 ; 34.8 \%$ vs. $21.1 \%$ ). The yeast count was lower in the MIX silages than in the LPT silages $(p<0.05)$ due to a higher concentration of acetate in MIX silages $(p<0.05)$. Aerobic stability was highest in the wilted MIX silages $(p<0.05)$. In conclusion, the MIX inoculation increased aerobic stability and improved fiber digestibility. As a result of the wilting process, ammonia- $\mathrm{N}$ in silage decreased but ruminal ammonia- $\mathrm{N}$ increased. Notably, the wilted silage with applied mixed inoculant had the highest aerobic stability.

Keywords: bacteria inoculant; rumen fermentation; rye silage; wilting

\section{Introduction}

The improvement of silage quality through bacterial additive has been commonly applied in the field. Even though improved ensiling processes, bacterial additives are not always guaranteed to reduce contamination by undesirable microbes after silo open [1] Recently, many researchers revealed that lactic acid bacteria (LAB) can produce antifungal activity to reduce contamination by undesirable microbes on silage, especially after silo open [2-4]. In addition, acetate and propionate produced by LAB inhibit the growth of fungi during ensiling through cell wall breakage and mitochondria apoptosis, respectively $[5,6]$. According to previous studies, the application of LAB producing antifungal activity can reduce the growth of undesirable microbes and increase the aerobic stability of silage [3,4]. On the other hand, some forages are characterized by high structural carbohydrate and low soluble carbohydrate, which reduce either ensiling quality or digestibility [7]. In addition, an increased concentration of lignocellulose reduces the digestibility of silage in the rumen [8]. Several strains of LAB were reported to produce fibrinolytic enzymes such as esterase and xylanase, which could help to degrade structural carbohydrate and improve ruminal digestibility [8,9]. Application of LAB producing fibrinolytic activity on silage was reported to increase ruminal digestibility in many previous studies $[4,8]$. 
In South Korea, rye (Secale cereale L.) is a main winter forage for ruminant diet [10]. According to Kim et al. [11], rye has high adaptability and resistance in acid soil and also can be grown by double-cropping in rice paddies. In the field, rye produces high dry matter (DM) yield to maintain the requirement of a roughage source during winter season for ruminants. However, it also contains a high concentration of lignocellulose [12]. Until recently, studies concerned with scientific approaches to improving rye silage were limited compared to studies of other silages.

In our previous study, Leuconostoc holzapfelii $5 \mathrm{H} 4$ and Lactobacillus brevis 100D8 were isolated from rye silage and selected on the basis of their fibrinolytic and antifungal activity, respectively [2,13]. According to Kim et al. [2], L. brevis 100D8 has eight putative antibiotic biosynthesis genes that improve antifungal activity. In contrast, Leuc. holzapfelii $5 \mathrm{H} 4$ has genes encoding for esterase, cellulase, and xylanase protein, which can help to improve ruminal digestibility [13]. Paradhipta et al. [14] confirmed that L. brevis 100D8 produces antifungal activity, while Leuc. holzapfelii $5 \mathrm{H} 4$ produces fibrinolytic activity on rye silage. However, the effectiveness of selected LAB compared to commercial bacterial additive was not yet known. In addition, differences in moisture concentration of rye through the wilting process might also affect the improvement of silage quality by selected LAB. In the present study, L. brevis 100D8 and Leuc. holzapfelii 5H4 were mixed as silage inoculant to produce dual activities. In our hypothesis, the application of selected inoculant could produce better silage quality to improve ruminal digestibility and aerobic stability than commercial inoculant. Therefore, the present study was conducted to determine the effects of dual-activity inoculant on the fermentation quality and in vitro digestibility of rye silage at different wilting times compared to commercial inoculant.

\section{Materials and Methods}

\subsection{Inoculant Preparation}

The selected inoculant was produced at the animal research unit, Gyeongsang Animal Science and Technology (GAST), Jinju, South Korea. The selected inoculant consisted of L. brevis strain 100D8 and Leuc. holzapfelii strain 5H4 at a 1:1 ratio. Approximately $2 \mathrm{~L}$ of inoculant was mixed with $500 \mathrm{~L}$ of culture medium (glucose $14,000 \mathrm{~g}$, soy peptone $1750 \mathrm{~g}$, yeast extract $7000 \mathrm{~g}$, magnesium sulfate $350 \mathrm{~g}$, manganese sulfate $140 \mathrm{~g}$, salt $350 \mathrm{~g}$, sodium phosphate dibasic $2100 \mathrm{~g}$, calcium carbonate $117 \mathrm{~g}$, and $\mathrm{NaOH}$ for $\mathrm{pH}$ control). The inoculant was incubated at $35^{\circ} \mathrm{C}$ for $12 \mathrm{~h}$ and then freeze-dried for $5 \mathrm{~d}$.

\subsection{Silage Production}

Rye forage was grown in the animal research unit, Gyeongsang National University, Jinju, South Korea and harvested at the early dough stage (34.7\% DM). The harvested rye was wilted under the sun as follows: (1) unwilted (UW) containing $34.7 \% \mathrm{DM}$; and (2) wilted for $12 \mathrm{~h}$ (WIL) containing $42.8 \%$ DM. Each rye forage was chopped into $3-5 \mathrm{~cm}$ lengths using a conventional harvester (BHC-90, BUHEUNG Machinery Ltd., Jinju, South Korea) and treated with different inoculants as follows: (1) commercial inoculant containing Lactobacillus plantarum sp. with application rate of $8.0 \times 10^{5}$ colony forming units (cfu) $/ \mathrm{g}$ of fresh forage (LPT); and (2) selected inoculant consisting of L. brevis strain 100D8 and Leuc. holzapfelii strain 5H4 in 1:1 ratio with application rate of $7.5 \times 10^{5} \mathrm{cfu} / \mathrm{g}$ of fresh forage (MIX). All forages were ensiled into $20 \mathrm{~L}$ mini silos $(5 \mathrm{~kg})$ for $100 \mathrm{~d}$ in quadruplicate. Thus, a total of 16 silos were prepared in the present study. The rye forages before and after ensiling were sub-sampled at $500 \mathrm{~g}$, respectively, to analyze chemical composition and in vitro digestibility. Also, $20 \mathrm{~g}$ of rye silage was sub-sampled and blended with $200 \mathrm{~mL}$ of sterile ultrapure water for $30 \mathrm{sec}$, and then filtered through 2 layers of cheesecloth to produce silage extract. The fresh silage extraction was used to analyze $\mathrm{pH}$. Afterward, the silage extraction was stored at $-70{ }^{\circ} \mathrm{C}$ until the analyses of ammonia- $\mathrm{N}$, lactate, and volatile fatty acid (VFA). 


\subsection{Chemical Composition and In Vitro Digestiblity}

The sub-sampled rye forage and silage $(10 \mathrm{~g})$ were dried at $105^{\circ} \mathrm{C}$ for $24 \mathrm{~h}$ to measure the DM concentration. Approximately $200 \mathrm{~g}$ of each silage sub-sample was collected, dried at $60{ }^{\circ} \mathrm{C}$ for $48 \mathrm{~h}$, and ground using a cutting mill (Shinmyung Electric Co., Ltd., Gimpo, South Korea) to pass through a $1 \mathrm{~mm}$ screen. The crude ash concentration (CA) was determined using a muffle furnace at $550{ }^{\circ} \mathrm{C}$ for $5 \mathrm{~h}$. The crude protein $(\mathrm{CP})$ and ether extract (EE) concentrations were analyzed by the Kjeldahl method (method 984.13) and the Soxhlet method (method 920.39), respectively. The neutral detergent fiber (NDF; method 2002.04) and acid detergent fiber (ADF; method 973.18) concentrations were determined using an Ankom ${ }^{200}$ fiber analyzer (Ankom Technology, Macedon, NY, USA). All protocols for the $\mathrm{CP}, \mathrm{EE}, \mathrm{NDF}$, and ADF analyses were described by AOAC [15]. Hemicellulose (HEMI) was determined by calculating the difference between the NDF and ADF. The in vitro digestibility of DM (IVDMD) and NDF (IVNDFD) was determined by following the method of Tilley and Terry [16] using Ankom ${ }^{\text {II }}$ Daisy Incubators (Ankom Tech., Macedon, NY, USA).

\subsection{Fermentation Characteristics}

The $\mathrm{pH}$ and ammonia-N concentration were measured using $\mathrm{pH}$ meter (SevenEasy, Mettler Toledo, Switzerland) and colorimetry assay [17], respectively. The silage extract was centrifuged at $5645 \times g$ for $15 \mathrm{~min}$, and the supernatant was used to measure the lactate and VFA concentrations using HPLC (L-2200; Hitachi, Tokyo, Japan) fitted with a UV detector (L-2400; Hitachi) and a column (Metacarb 87H; Varian, CA, USA) described by Adesogan et al. [18].

\subsection{Microbial Enumerations}

About $20 \mathrm{~g}$ of silage samples from each treatment were diluted with $180 \mathrm{~mL}$ of distilled water and macerated in a blender to obtain the silage extract for the enumeration of LAB, yeast, and mold. Considering the silage extract as the first dilution, serial dilutions were prepared and $100 \mu \mathrm{L}$ aliquots of 3 consecutive dilutions $\left(10^{-4}, 10^{-5}\right.$, and $\left.10^{-6}\right)$ were plated in triplicate onto a selective agar medium. Lactobacilli MRS agar media (MRS; Difco, Detroit, MI, USA) was used to culture LAB, and potato dextrose agar (PDA; Difco, Detroit, MI, USA) was used for yeast and mold. The MRS agar plates were placed in $\mathrm{CO}_{2}$ incubator (Thermo Scientific, Waltham, MA, USA) at $30{ }^{\circ} \mathrm{C}$ for $72 \mathrm{~h}$, while the PDA plates were incubated at $30^{\circ} \mathrm{C}$ for $72 \mathrm{~h}$ in a normal incubator (Johnsam Corporation, Boocheon, South Korea). Visible colonies were counted from the plates, and the number of cfu was expressed per gram of silage. The microbial data were transformed to $\log 10$.

\subsection{Rumen Fermentation}

The animal care produce was approved by the Animal Ethical Committee of Gyeongsang National University, Jinju, South Korea. The rumen fluid was collected from two non-pregnant cannulated Hanwoo heifers before morning feeding. Their diets consisted of rice straw and commercial concentrate mix at a ratio of 8:2. The collected rumen fluid was composited and filtered through 2 layers of cheesecloth. A rumen buffer was prepared by mixing rumen fluid with anaerobic culture medium at a 1:2 ratio, as described by Adesogan et al. [19]. Dried samples of rye silage $(0.5 \mathrm{~g})$ were weighed into an incubation bottle with $40 \mathrm{~mL}$ of rumen buffer. Then, the incubation bottle was gassed with $\mathrm{CO}_{2}$ and closed tightly to reach anaerobic conditions. Samples were incubated in triplicate for $0,1,3,6,12,24,48$, and $72 \mathrm{~h}$ with 2 blanks for each time. The gas pressure was measured using a manometer pressure/vacuum gauge monitor (Fisher Scientific, Traceable, Friendswood, TX, USA) to calculate the rumen fermentation kinetics. The kinetics were generated from the gas pressure using the nonlinear regression procedure of SAS [20] to fit with the model of McDonald [21], as follows:

$$
\mathrm{Y}=\mathrm{A}+\mathrm{B}\left(1-\mathrm{e}^{-\mathrm{c}(\mathrm{t}-\mathrm{L})}\right) \text { for } \mathrm{t}>\mathrm{L}
$$


where $\mathrm{A}$ is the immediately degradable fraction, $\mathrm{B}$ is the potentially degradable fraction, $\mathrm{A}+\mathrm{B}$ is the total degradable fraction, $\mathrm{C}$ is the fractional degradation rate, $\mathrm{L}$ is lag phase, and $t$ is time of incubation (h).

The bottles incubated for $72 \mathrm{~h}$ were opened and transferred to a $50 \mathrm{~mL}$ conical tube to separate the remaining sample and supernatant (rumen buffer) through centrifugation at $2568 \times g$ for 15 min (Supra 21k, Hanil Electric Corporation, Seoul, South Korea, with rotor A50S-6C No.6). The supernatant was used to analyze rumen fermentation characteristics such as the $\mathrm{pH}$, ammonia- $\mathrm{N}$, and VFA. The procedure for the analyses of $\mathrm{pH}$, ammonia-N, and VFA were the same as described in the previous section.

\subsection{Statistical Analysis}

This experiment had a completely randomized design with a 2 (wilting; UW vs. WIL) $\times 2$ (inoculant; LPT vs. MIX) factorial arrangement of the treatments. All data on the chemical composition, fermentation characteristics, microbe counts, and temperature of the silages were analyzed using PROC MIXED of SAS [20] and a model containing the day, inoculant, and interactions of these terms. The model was $Y_{i j k}=\mu+\alpha_{i}+\beta_{j}+(\alpha \beta)_{i j}+e_{i j k}$, where $Y_{i j k}=$ response variable, $\mu$ = overall mean, $\alpha_{i}=$ effect of time treatment, $\beta_{j}=$ effect of inoculant treatment, $(\alpha \beta)_{i j}=$ the interaction effect of time and inoculant, and $e_{i j k}=$ error term. Mean separation was performed using a Tukey's test. Significant differences were declared at $p<0.05$.

\section{Results}

\subsection{Chemical Compositions and In Vitro Digestibility}

Wilted rye forage had a higher DM concentration ( $p<0.001 ; 42.8 \%$ vs. $34.7 \%$ ) than unwilted rye forage (Table 1). The mean concentrations of CP, EE, CA, NDF, ADF, and HEMI in rye forages were $5.98 \%, 1.98 \%, 5.16 \%, 72.0 \%, 42.3 \%$, and $29.7 \%$, respectively. The UW silages had a higher concentration of DM ( $p<0.001 ; 32.9 \%$ vs. $40.0 \%)$ than WIL silages (Table 2). The MIX silages had higher concentrations of NDF ( $p<0.001 ; 73.7 \%$ vs. $70.9 \%$ ), HEMI ( $p=0.005 ; 31.8 \%$ vs. $29.4 \%$ ), IVDMD ( $p=0.005 ; 55.2 \%$ vs. $51.2 \%$ ), and IVNDFD $(p=0.045 ; 45.9 \%$ vs. $43.7 \%)$ than LPT silages.

Table 1. Effects of wilting and inoculants on chemical compositions of rye forage before ensiling (\%, DM).

\begin{tabular}{|c|c|c|c|c|c|c|c|}
\hline \multirow{2}{*}{\multicolumn{2}{|c|}{ Item $^{1}$}} & \multicolumn{2}{|c|}{ UW } & & \multicolumn{2}{|c|}{ WIL } & \multirow{2}{*}{ SEM } \\
\hline & & LPT & MIX & & LPT & MIX & \\
\hline \multicolumn{2}{|c|}{$\mathrm{DM}$} & $34.7^{b}$ & $34.6^{b}$ & & $42.8^{a}$ & $42.8^{\mathrm{a}}$ & 0.891 \\
\hline \multicolumn{2}{|c|}{$\mathrm{CP}$} & 5.88 & 5.84 & & 6.13 & 6.06 & 0.247 \\
\hline \multicolumn{2}{|c|}{$\mathrm{EE}$} & 1.83 & 2.17 & & 1.97 & 1.96 & 0.258 \\
\hline \multicolumn{2}{|c|}{$\mathrm{CA}$} & 5.05 & 5.27 & & 5.13 & 5.18 & 0.181 \\
\hline \multicolumn{2}{|c|}{ NDF } & 72.3 & 71.9 & & 72.5 & 71.3 & 1.006 \\
\hline \multicolumn{2}{|c|}{ ADF } & 42.7 & 41.8 & & 42.9 & 41.7 & 1.053 \\
\hline \multicolumn{2}{|c|}{ HEMI } & 29.6 & 30.0 & & 29.6 & 29.6 & 0.436 \\
\hline Contrast & $\mathrm{DM}$ & $\mathrm{CP}$ & $\mathrm{EE}$ & CA & $\mathrm{NDF}$ & $\mathrm{ADF}$ & HEMI \\
\hline WT & $<0.001$ & 0.134 & 0.811 & 0.924 & 0.878 & 0.977 & 0.214 \\
\hline INO & 0.863 & 0.694 & 0.263 & 0.162 & 0.165 & 0.103 & 0.585 \\
\hline $\mathrm{WT} \times \mathrm{INO}$ & 0.888 & 0.928 & 0.241 & 0.366 & 0.469 & 0.774 & 0.639 \\
\hline
\end{tabular}

${ }^{1} \mathrm{UW}$, un-wilting; WIL, wilting for $12 \mathrm{~h}$; LPT, L. plantarum $\left(8.0 \times 10^{5} \mathrm{cfu} / \mathrm{g}\right)$; MIX, mixture of Lactobacillus brevis strain 100D8 and Leuconostoc holzapfelii strain $5 \mathrm{H} 4$ at 1:1 ratio $\left(7.5 \times 10^{5} \mathrm{cfu} / \mathrm{g}\right)$; DM, dry matter; $\mathrm{CP}$, crude protein; EE, ether extract; CA, crude ash; NDF, neutral detergent fiber; ADF, acid detergent fiber; HEMI, hemicellulose; WT, wilting effect; INO, inoculant effect; WT $\times$ INO, interaction effect between wilting and inoculant; SEM, standard error of the mean. ${ }^{a, b}$ Means in the same row with different superscripts differ significantly $(p<0.05)$. 
Table 2. Effects of wilting and inoculants on chemical compositions and in vitro digestibility of rye silage ensiled for $100 \mathrm{~d}$ $(\%, \mathrm{DM})$.

\begin{tabular}{|c|c|c|c|c|c|c|c|c|c|}
\hline \multirow{2}{*}{\multicolumn{2}{|c|}{ Item $^{1}$}} & \multicolumn{2}{|c|}{ UW } & & \multicolumn{4}{|c|}{ WIL } & \multirow{2}{*}{ SEM } \\
\hline & & LPT & MIX & & \multicolumn{2}{|c|}{ LPT } & \multicolumn{2}{|c|}{ MIX } & \\
\hline \multicolumn{2}{|c|}{$\mathrm{DM}$} & $33.3^{b}$ & $32.5^{b}$ & & \multicolumn{2}{|c|}{$40.5^{a}$} & \multicolumn{2}{|c|}{$39.5^{a}$} & 0.922 \\
\hline \multicolumn{2}{|c|}{$\mathrm{CP}$} & 7.07 & 6.94 & & \multicolumn{2}{|c|}{6.96} & \multicolumn{2}{|c|}{7.13} & 0.428 \\
\hline \multicolumn{2}{|c|}{$\mathrm{EE}$} & 3.86 & 3.61 & & \multicolumn{2}{|c|}{3.84} & \multicolumn{2}{|c|}{3.35} & 0.376 \\
\hline \multicolumn{2}{|c|}{ CA } & 5.39 & 5.50 & & \multicolumn{2}{|c|}{5.33} & \multicolumn{2}{|c|}{5.40} & 0.102 \\
\hline \multicolumn{2}{|c|}{ NDF } & $71.5^{b}$ & $73.8^{a}$ & & \multicolumn{2}{|c|}{$70.2^{b}$} & \multicolumn{2}{|c|}{$73.5^{a}$} & 0.802 \\
\hline \multicolumn{2}{|c|}{ ADF } & 41.9 & 41.6 & & \multicolumn{2}{|c|}{41.4} & \multicolumn{2}{|c|}{42.2} & 0.903 \\
\hline \multicolumn{2}{|c|}{ HEMI } & 30.0 & 32.2 & & \multicolumn{2}{|c|}{28.8} & \multicolumn{2}{|c|}{31.3} & 1.117 \\
\hline \multicolumn{2}{|c|}{ IVDMD } & $52.5^{\mathrm{ab}}$ & $56.7^{\mathrm{a}}$ & & \multicolumn{2}{|c|}{$49.8^{\mathrm{b}}$} & \multicolumn{2}{|c|}{$53.6^{\mathrm{ab}}$} & 1.657 \\
\hline \multicolumn{2}{|c|}{ IVNDFD } & $45.1^{\mathrm{ab}}$ & $46.9^{\mathrm{a}}$ & & \multicolumn{2}{|c|}{$42.2^{b}$} & \multicolumn{2}{|c|}{$44.9^{\mathrm{ab}}$} & 1.215 \\
\hline Contrast & $\mathrm{DM}$ & $\mathrm{CP}$ & $\mathrm{EE}$ & CA & $\mathrm{NDF}$ & $\mathrm{ADF}$ & HEMI & IVDMD & IVNDFD \\
\hline WT & $<0.001$ & 0.837 & 0.537 & 0.176 & 0.081 & 0.915 & 0.364 & 0.013 & 0.028 \\
\hline INO & 0.102 & 0.912 & 0.119 & 0.112 & $<0.001$ & 0.696 & 0.005 & 0.005 & 0.045 \\
\hline $\mathrm{WT} \times \mathrm{INO}$ & 0.849 & 0.494 & 0.590 & 0.724 & 0.251 & 0.301 & 0.822 & 0.874 & 0.564 \\
\hline
\end{tabular}

${ }^{1} \mathrm{UW}$, un-wilting; WIL, wilting for $12 \mathrm{~h}$; LPT, L. plantarum $\left(8.0 \times 10^{5} \mathrm{cfu} / \mathrm{g}\right)$; MIX, mixture of Lactobacillus brevis strain 100D8 and Leuconostoc holzapfelii strain $5 \mathrm{H} 4$ at 1:1 ratio $\left(7.5 \times 10^{5} \mathrm{cfu} / \mathrm{g}\right)$; DM, dry matter; $\mathrm{CP}$, crude protein; EE, ether extract; CA, crude ash; NDF, neutral detergent fiber; ADF, acid detergent fiber; HEMI, hemicellulose; WT, wilting effect; INO, inoculant effect; WT $\times$ INO, interaction effect between wilting and inoculant; SEM, standard error of the mean. ${ }^{a, b}$ Means in the same row with different superscripts differ significantly $(p<0.05)$.

\subsection{Fermentation Characteristics}

The MIX silages had a higher $\mathrm{pH}$ value $(p<0.001 ; 4.10$ vs. 4.62$)$ and concentration of acetate $(p<0.001 ; 4.48 \%$ vs. $0.88 \%$ ) than LPT silage (Table 3$)$. However, the MIX silages had lower lactate to acetate ratio ( $p<0.001 ; 0.10$ vs. 7.41$)$. The interaction effects between wilting and inoculant were shown in ammonia-N ( $p=0.010)$; MIX was only effective in reducing ammonia-N on WIL silage. The interaction effects between wilting and inoculant were also presented in lactate $(p=0.012)$ and propionate $(p<0.001)$. It could be seen that only on UW silage, LPT and MIX were effective in increasing $(p<0.05)$ concentrations of lactate and propionate, respectively. The concentration of butyrate was not detected in any of the treatments.

Table 3. Effects of wilting and inoculants on fermentation characteristics of rye silage ensiled for $100 \mathrm{~d}$.

\begin{tabular}{|c|c|c|c|c|c|c|c|}
\hline \multirow{2}{*}{\multicolumn{2}{|c|}{ Item $^{1}$}} & \multicolumn{2}{|c|}{ UW } & & \multicolumn{2}{|c|}{ WIL } & \multirow{2}{*}{ SEM } \\
\hline & & LPT & MIX & & LPT & MIX & \\
\hline \multicolumn{2}{|c|}{$\mathrm{pH}$} & $4.06^{b}$ & $4.58^{a}$ & & $4.14^{\mathrm{b}}$ & $4.65^{\mathrm{a}}$ & 0.043 \\
\hline \multicolumn{2}{|c|}{ Ammonia-N, \% DM } & $0.026^{b c}$ & $0.041^{\mathrm{a}}$ & & $0.022^{c}$ & $0.029^{b}$ & 0.003 \\
\hline \multicolumn{2}{|c|}{ Lactate, \% DM } & $7.40^{\mathrm{a}}$ & $0.24^{\mathrm{c}}$ & & $5.30^{b}$ & $0.61^{c}$ & 0.647 \\
\hline \multicolumn{2}{|c|}{ Acetate, \% DM } & $1.11^{\mathrm{b}}$ & $4.74^{\mathrm{a}}$ & & $0.65^{b}$ & $4.22^{\mathrm{a}}$ & 1.062 \\
\hline \multicolumn{2}{|c|}{ Propionate, \% DM } & $\mathrm{ND}^{\mathrm{b}}$ & $0.05^{\mathrm{a}}$ & & $\mathrm{ND}^{\mathrm{b}}$ & $0.01^{b}$ & 0.004 \\
\hline \multicolumn{2}{|c|}{ Butyrate, \% DM } & ND & ND & & ND & ND & $\mathrm{N} / \mathrm{A}$ \\
\hline \multicolumn{2}{|c|}{ Lactate:acetate ratio } & $6.66^{\mathrm{a}}$ & $0.05^{\mathrm{b}}$ & & $8.15^{a}$ & $0.14^{b}$ & 0.705 \\
\hline Contrast & $\mathrm{pH}$ & Ammonia-N & Lactate & Acetate & Propionate & Butyrate & $\mathrm{L}: \mathrm{A}$ \\
\hline WT & 0.016 & $<0.001$ & 0.055 & 0.198 & $<0.001$ & $\mathrm{~N} / \mathrm{A}$ & 0.087 \\
\hline INO & $<0.001$ & $<0.001$ & $<0.001$ & $<0.001$ & $<0.001$ & $\mathrm{~N} / \mathrm{A}$ & $<0.001$ \\
\hline $\mathrm{WT} \times \mathrm{INO}$ & 0.709 & 0.010 & 0.012 & 0.963 & $<0.001$ & $\mathrm{~N} / \mathrm{A}$ & 0.116 \\
\hline
\end{tabular}

${ }^{1} \mathrm{UW}$, un-wilting; WIL, wilting for $12 \mathrm{~h}$; LPT, L. plantarum $\left(8.0 \times 10^{5} \mathrm{cfu} / \mathrm{g}\right)$; MIX, mixture of Lactobacillus brevis strain $100 \mathrm{D} 8$ and Leuconostoc holzapfelii strain $5 \mathrm{H} 4$ at 1:1 ratio $\left(7.5 \times 10^{5} \mathrm{cfu} / \mathrm{g}\right)$; L:A, lactate to acetate ratio; WT, wilting effect; INO, inoculant effect; WT $\times$ INO, interaction effect between wilting and inoculant; SEM, standard error of the mean; ND, $<0.01 \%$ DM; N/A, not applicable. ${ }^{a-c}$ Means in the same row with different superscripts differ significantly $(p<0.05)$. 


\subsection{Microbial Counts}

The MIX silages had lower yeast count $(p<0.001 ; 4.79 \log 10 \mathrm{cfu} / \mathrm{g}$ vs. $5.75 \log 10 \mathrm{cfu} / \mathrm{g}$ ) than LPT silage (Table 4). The interaction effects between wilting and inoculant were shown in LAB $(p=0.015)$ and aerobic stability $(p<0.001)$; MIX was effective in increasing $(p<0.05)$ aerobic stability only on WIL silage. Mold was not detected in any of the treatments.

Table 4. Effects of wilting and inoculants on microbial counts and aerobic stability of rye silage ensiled for $100 \mathrm{~d}$.

\begin{tabular}{|c|c|c|c|c|c|c|}
\hline \multirow{2}{*}{\multicolumn{2}{|c|}{ Item $^{1}$}} & \multicolumn{2}{|c|}{ UW } & \multicolumn{2}{|c|}{ WIL } & \multirow{2}{*}{ SEM } \\
\hline & & LPT & MIX & LPT & MIX & \\
\hline \multicolumn{2}{|c|}{$\mathrm{LAB}, \log _{10} \mathrm{cfu} / \mathrm{g}$} & $5.77^{\mathrm{c}}$ & $7.84^{\mathrm{a}}$ & $5.57^{\mathrm{c}}$ & $6.72^{b}$ & 0.322 \\
\hline \multicolumn{2}{|c|}{ Yeast, $\log _{10} \mathrm{cfu} / \mathrm{g}$} & $5.55^{\mathrm{a}}$ & $4.84^{\mathrm{b}}$ & $5.94^{\mathrm{a}}$ & $4.73^{b}$ & 0.270 \\
\hline \multicolumn{2}{|c|}{ Mold, $\log _{10} \mathrm{cfu} / \mathrm{g}$} & ND & ND & ND & ND & $\mathrm{N} / \mathrm{A}$ \\
\hline \multicolumn{2}{|c|}{ Aerobic stability, $\mathrm{h}$} & $39.4^{\mathrm{c}}$ & $430.7^{b}$ & $53.7^{\mathrm{c}}$ & $722.0^{a}$ & 12.77 \\
\hline Contrast & LAB & & Yeast & Mold & \multicolumn{2}{|c|}{ Aerobic stability } \\
\hline WT & 0.002 & & 0.713 & N/A & \multicolumn{2}{|c|}{$<0.001$} \\
\hline INO & $<0.001$ & & $<0.001$ & $\mathrm{~N} / \mathrm{A}$ & \multicolumn{2}{|c|}{$<0.001$} \\
\hline $\mathrm{WT} \times \mathrm{INO}$ & 0.015 & & 0.156 & $\mathrm{~N} / \mathrm{A}$ & \multicolumn{2}{|c|}{$<0.001$} \\
\hline
\end{tabular}

${ }^{1} \mathrm{UW}$, un-wilting; WIL, wilting for $12 \mathrm{~h}$; LPT, L. plantarum $\left(8.0 \times 10^{5} \mathrm{cfu} / \mathrm{g}\right)$; MIX, mixture of Lactobacillus brevis strain 100D8 and Leuconostoc holzapfelii strain $5 \mathrm{H} 4$ at 1:1 ratio $\left(7.5 \times 10^{5} \mathrm{cfu} / \mathrm{g}\right)$; WT, wilting effect; INO, inoculant effect; WT $\times$ INO, interaction effect between wilting and inoculant; SEM, standard error of the mean; ND, $<4.0 \log 10 \mathrm{cfu} / \mathrm{g} .{ }^{\mathrm{a}-\mathrm{c}}$ Means in the same row with different superscripts differ significantly $(p<0.05)$.

\subsection{Rumen Fermentation Kinetics}

The MIX silages had a higher immediately fermentable fraction $(p<0.001 ; 0.38 \mathrm{~mL} / \mathrm{g}$ vs. $0.25 \mathrm{~mL} / \mathrm{g}$ ) but a lower fractional fermentation rate ( $p=0.004 ; 0.04$ vs. 0.05$)$ than LPT silages (Table 5). The interaction effects between wilting and inoculant were shown in the potentially fermentable fraction $(p=0.017)$ and the total fermentable fraction $(p=0.020)$; LPT was effective in increasing $(p<0.05)$ the potentially fermentable fraction and the total fermentable fraction on WIL silage. The interaction effects between wilting and inoculant were also presented in the lag phase $(p=0.021)$, and it could be seen that LPT was effective in decreasing $(p<0.05)$ lag phase only on WIL silage.

Table 5. Effects of wilting and inoculants on rumen fermentation kinetics of rye silage incubated with rumen buffer for $72 \mathrm{~h}$.

\begin{tabular}{|c|c|c|c|c|c|}
\hline \multirow{2}{*}{ Item $^{1}$} & \multicolumn{2}{|c|}{ UW } & \multicolumn{2}{|c|}{ WIL } & \multirow{2}{*}{ SEM } \\
\hline & LPT & MIX & LPT & MIX & \\
\hline $\mathrm{A}, \mathrm{mL} / \mathrm{g}$ of $\mathrm{DM}$ & $0.26^{b}$ & $0.37^{\mathrm{a}}$ & $0.23^{b}$ & $0.38^{\mathrm{a}}$ & 0.027 \\
\hline $\mathrm{B}, \mathrm{mL} / \mathrm{g}$ of $\mathrm{DM}$ & $12.5^{b}$ & $14.3^{\mathrm{ab}}$ & $16.3^{\mathrm{a}}$ & $15.3^{\mathrm{a}}$ & 0.825 \\
\hline $\mathrm{A}+\mathrm{B}, \mathrm{mL} / \mathrm{g}$ of $\mathrm{DM}$ & $12.8^{\mathrm{b}}$ & $14.7^{\mathrm{ab}}$ & $16.5^{\mathrm{a}}$ & $15.7^{\mathrm{a}}$ & 0.838 \\
\hline $\mathrm{C}, \% / \mathrm{h}$ & $0.06^{\mathrm{a}}$ & $0.04^{\mathrm{ab}}$ & $0.03^{b}$ & $0.04^{b}$ & 0.006 \\
\hline $\mathrm{L}, \mathrm{h}$ & $2.67^{\mathrm{a}}$ & $2.41^{\mathrm{ab}}$ & $1.74^{\mathrm{b}}$ & $2.60^{a b}$ & 0.342 \\
\hline Contrast & A & B & $A+B$ & $\mathrm{C}$ & $\mathrm{L}$ \\
\hline WT & 0.575 & 0.001 & 0.001 & 0.004 & 0.097 \\
\hline INO & $<0.001$ & 0.429 & 0.308 & 0.351 & 0.166 \\
\hline $\mathrm{WT} \times \mathrm{INO}$ & 0.162 & 0.017 & 0.020 & 0.052 & 0.021 \\
\hline
\end{tabular}

${ }^{1} \mathrm{UW}$, un-wilting; WIL, wilting for $12 \mathrm{~h}$; LPT, L. plantarum $\left(8.0 \times 10^{5} \mathrm{cfu} / \mathrm{g}\right)$; MIX, mixture of Lactobacillus brevis strain 100D8 and Leuconostoc holzapfelii strain $5 \mathrm{H} 4$ at 1:1 ratio $\left(7.5 \times 10^{5} \mathrm{cfu} / \mathrm{g}\right) ; \mathrm{A}$, the immediately fermentable fraction; $\mathrm{B}$, the potentially fermentable fraction; $\mathrm{A}+\mathrm{B}$, the total fermentable fraction; $\mathrm{C}$, the fractional fermentation rate; $\mathrm{L}$, the lag phase; WT, wilting effect; INO, inoculant effect; $\mathrm{WT} \times \mathrm{INO}$, interaction effect between wilting and inoculant; SEM, standard error of the mean. ${ }^{\mathrm{a}, \mathrm{b}}$ Means in the same row with different superscripts differ significantly $(p<0.05)$. 


\subsection{Rumen Fermentation Characteristics}

The WIL silages had higher concentrations of ammonia-N ( $p<0.001 ; 34.8$ vs. $21.1 \mathrm{mg} / \mathrm{dL}$ ), iso-butyrate ( $p=0.022 ; 1.34 \%$ vs. $1.21 \%$ molar), butyrate ( $p=0.015 ; 13.9 \%$ vs. $13.2 \%$ molar), and valerate ( $p=0.018 ; 1.56 \%$ vs. $1.16 \%$ molar) than UW silage (Table 6$)$. The MIX silages had a higher concentration of acetate $(p<0.001 ; 61.4 \%$ vs. $60.3 \%$ molar $)$ and iso-valerate $(p=0.020$; $3.09 \%$ vs. $2.69 \%$ molar) than LPT silage. The interaction effects between wilting and inoculant were shown in total VFA $(p=0.026)$, the concentration of which was effectively improved $(p<0.05)$ by MIX only on UW silage. The interaction effects between wilting and inoculant were shown in propionate $(p=0.007)$, and acetate to propionate ratio $(p=0.005)$. It could be seen that only on UW silage, LPT could increase $(p<0.05)$ propionate and decrease $(p<0.05)$ the ratio of acetate to propionate effectively.

Table 6. Effects of wilting and inoculants on rumen $\mathrm{pH}$, ammonia-N, and volatile fatty acids of rye silage incubated with rumen buffer for $72 \mathrm{~h}$.

\begin{tabular}{|c|c|c|c|c|c|c|c|c|c|c|}
\hline \multirow{2}{*}{\multicolumn{3}{|c|}{ Item $^{1}$}} & \multicolumn{3}{|c|}{ UW } & & \multicolumn{3}{|c|}{ WIL } & \multirow{2}{*}{ SEM } \\
\hline & & & LPT & \multicolumn{2}{|c|}{ MIX } & & \multicolumn{2}{|c|}{ LPT } & MIX & \\
\hline \multicolumn{3}{|c|}{$\mathrm{pH}$} & 6.03 & \multicolumn{2}{|c|}{5.97} & & \multicolumn{2}{|c|}{5.94} & 5.98 & 0.043 \\
\hline \multicolumn{3}{|c|}{ Ammonia-N, mg/dL } & $21.4^{\mathrm{b}}$ & \multicolumn{2}{|c|}{$20.7^{b}$} & & \multicolumn{2}{|c|}{$34.5^{\mathrm{a}}$} & $35.0^{\mathrm{a}}$ & 0.599 \\
\hline \multicolumn{3}{|c|}{ Total VFA, mM/L } & $71.2^{b}$ & \multicolumn{2}{|c|}{$104.4^{\mathrm{a}}$} & & \multicolumn{2}{|c|}{$89.0^{\mathrm{ab}}$} & $90.6^{\mathrm{ab}}$ & 6.505 \\
\hline \multicolumn{3}{|c|}{ Acetate, $\%$ of molar } & $60.1^{b}$ & \multicolumn{2}{|c|}{$61.5^{\mathrm{a}}$} & & \multicolumn{2}{|c|}{$60.4^{\mathrm{b}}$} & $61.3^{\mathrm{a}}$ & 0.214 \\
\hline \multicolumn{3}{|c|}{ Propionate, \% of molar } & 22.1 & \multicolumn{2}{|c|}{19.5} & & \multicolumn{2}{|c|}{19.3} & 19.1 & 0.588 \\
\hline \multicolumn{3}{|c|}{ Iso-butyrate, $\%$ of molar } & 1.16 & \multicolumn{2}{|c|}{1.26} & & \multicolumn{2}{|c|}{1.32} & 1.35 & 0.078 \\
\hline \multicolumn{3}{|c|}{ Butyrate, $\%$ of molar } & 13.1 & \multicolumn{2}{|c|}{13.2} & & \multicolumn{2}{|c|}{14.2} & 13.6 & 0.427 \\
\hline \multicolumn{3}{|c|}{ Iso-valerate, $\%$ of molar } & 2.46 & \multicolumn{2}{|c|}{2.96} & & \multicolumn{2}{|c|}{2.92} & 3.21 & 0.235 \\
\hline \multicolumn{3}{|c|}{ Valerate, $\%$ of molar } & 0.99 & \multicolumn{2}{|c|}{1.33} & & \multicolumn{2}{|c|}{1.65} & 1.46 & 0.228 \\
\hline \multicolumn{3}{|c|}{ Acetate:propionate ratio } & $2.74^{\mathrm{c}}$ & \multicolumn{2}{|c|}{$3.15^{\mathrm{ab}}$} & & \multicolumn{2}{|c|}{$3.10^{\mathrm{b}}$} & $3.24^{\mathrm{a}}$ & 0.034 \\
\hline Contrast & $\mathrm{pH}$ & $\mathrm{NH}_{3}-\mathrm{N}$ & TVFA & $\mathrm{AC}$ & PR & IBU & $\mathrm{BU}$ & IVA & VA & $\mathrm{A}: \mathrm{P}$ \\
\hline WT & 0.121 & $<0.001$ & 0.686 & 0.804 & 0.001 & 0.022 & 0.015 & 0.028 & 0.018 & $<0.001$ \\
\hline INO & 0.608 & 0.881 & 0.019 & $<0.001$ & 0.005 & 0.188 & 0.311 & 0.020 & 0.568 & $<0.001$ \\
\hline $\mathrm{WT} \times \mathrm{INO}$ & 0.080 & 0.210 & 0.026 & 0.056 & 0.007 & 0.503 & 0.175 & 0.455 & 0.076 & 0.005 \\
\hline
\end{tabular}

${ }^{1} \mathrm{UW}$, un-wilting; WIL, wilting for $12 \mathrm{~h}$; LPT, L. plantarum $\left(8.0 \times 10^{5} \mathrm{cfu} / \mathrm{g}\right)$; MIX, mixture of Lactobacillus brevis strain 100D8 and Leuconostoc holzapfelii strain $5 \mathrm{H} 4$ at $1: 1$ ratio $\left(7.5 \times 10^{5} \mathrm{cfu} / \mathrm{g}\right)$; $\mathrm{NH}_{3}-\mathrm{N}$, ammonia-N; TVFA, total volatile fatty acid; AC, acetate; PR, propionate; IBU, iso-butyrate; BU, butyrate; IVA, iso-valerate; VA, valerate; A:P, acetate to propionate ratio; WT, wilting effect; INO, inoculant effect; WT $\times$ INO, interaction effect between wilting and inoculant; SEM, standard error of the mean. ${ }^{a-c}$ Means in the same row with different superscripts differ significantly $(p<0.05)$.

\section{Discussion}

According to previous studies, generally, concentrations of $\mathrm{CP}, \mathrm{EE}, \mathrm{CA}, \mathrm{NDF}, \mathrm{ADF}$, and HEMI from rye forages were $6.48-10.6 \%, 1.49-2.22 \%, 5.13-6.11 \%, 70.5-74.4 \%, 45.9-46.2 \%$, and $24.8-48.2 \%$, respectively $[14,22]$. The results of the present study were slightly different from previous studies. This difference could have occurred because of different seed quantities and harvest times [14]. In general, hetero types of inoculant applications can result in a gradual decrease of silage $\mathrm{pH}$, which also leads to enhance proteolysis and water-soluble carbohydrate (WSC) loss. Zeng et al. [23] reported that the increase of NDF could occur due to the decrease of WSC or CP concentration by undesired bacteria. This explanation was consistent with the results of the present study showing that NDF concentration increased in MIX silage. In the present study, in vitro digestibility decreased with wilting time. Gomes et al. [24] and Chen et al. [25] reported that the in vitro digestibility of wilted silage could be decreased by the loss of soluble nutrients and lead to the increase of cell external wall density. On the other hand, cellulase and xylanase are well-known to cleave the binding of cellulose, HEMI, and glucans, thereby increasing the fiber digestibility [26]. In particular, the lignocellulose is difficult to be degraded by bacteria $[27,28]$. However, fibrinolytic enzymes such as ferulate esterases could enhance the degradation of lignocellulose into pentoses and lead to an increase in acetic acid concentration of silage [29]. 
Degrading lignocellulose could increase fiber digestibility in the rumen $[4,8,13]$. Again, Kim et al. [13] reported that the Leuc. holzapfelii strain 5H4 used in the MIX inoculant produced several fibrinolytic enzymes such as esterase, cellulose, and xylanase. Therefore, the increased IVDMD and IVNDFD in MIX silages are most likely the result of the Leuc. holzapfelii strain $5 \mathrm{H} 4$ application.

The L. plantarum used in the present study is known as a homofermentative LAB that produces lactate as a main metabolite product [30]. Lactate can decrease silage $\mathrm{pH}$ rapidly in the initial stage of the ensiling period, which can help reduce nutrient loss by the inhibition of undesirable microbes [18]. The present study also showed similar results of lower $\mathrm{pH}$ with higher lactate concentration in silage treated with the LPT application. Ammonia-N in silage, as a by-product of proteolysis, inhibits the decrease of silage $\mathrm{pH}$ [30]. The lower ammonia-N attributable to LPT application in the present study also could support lower $\mathrm{pH}$ in LPT silage (Table 3).

Leuc. holzapfelii and L. brevis were confirmed as heterofermentative LABs [2,13]. They could convert lactate into acetate and propionate, which are known as antifungal substances [31]. In addition, L. brevis 100D8 has genes encoding lanthionine synthetase C-like protein, which has a role as an antifungal substance to inhibit undesirable microbes [2]. In addition, Paul and Donk [32] also reported that lanthionine can inhibit the growth of silage mold species such as Aspergillus, Penicillium, and Fusarium. In the present study, the lower yeast count in MIX silages might be a result of Leuc. holzapfelii and L. brevis applications. Ranjit and Kung [33] reported that yeast assimilates lactic acid of silage during aerobic exposure, and leads to the deterioration of aerobic spoilage by the growth of mold. Similarly, in the present study, the lower aerobic stability in LPT silages could be attributable to higher yeast counts and acetic acid concentrations in those silages. Generally, wilting could lead to decreased aerobic stability due to the growth of undesirable microbes [34]. However, some studies have reported that a wilting process of less than $10 \mathrm{~h}$ or until $30-40 \%$ of DM had beneficial effects on the fermentation quality and aerobic stability of silages [35-37]. In addition, $\mathrm{Hu}$ et al. [38] also reported that moderately high DM silage, compared to normal DM silage (40.6\% vs. 33.1\%), had an improved LAB count and aerobic stability. The wilting effects on aerobic stability observed in the present study were in agreement with these previous studies.

Adesogan [39] reported that fibrinolytic enzymes such as cellulase, xylanase, and esterase can convert plant cell walls into mono- or oligosaccharide. In the present study, the reason for the increased immediately fermentable fraction in MIX silage might have been the Leuc. holzapfelii strain 5H4 application, which enhanced the secretion of fibrinolytic enzymes. Morgan et al. [40] reported that the rumen nitrogen of steers could be increased if they were fed high-quality ryegrass silage. Ruminal ammonia-N is the main nitrogen source for microbial protein synthesis in the rumen [41]. Moreover, the synthesized microbial protein in the rumen provides amino acids more efficiently than the feed protein fed to the ruminants [42]. Charmley and Veira [43] reported that the protease activity in alfalfa silage is inhibited by the wilting process. In the present study, the ammonia-N concentration of silage was also decreased by wilting, which might be caused by the inhibition of proteolysis (Table 3). The increase in ruminal ammonia- $\mathrm{N}$ concentration obtained with wilted silage in the present study could be supported by this evidence. The total VFA is known as the main energy source for the growth of ruminants and provides about $80 \%$ of the energy for ruminants [44]. Wan et al. [45] reported that total VFA concentration was positively correlated with the total fermentable fraction. This explanation is supported by the results of the present study for unwilted LPT silage, which had a low total fermentable fraction with low total VFA concentration. Meller et al. [46] reported that the concentration of acetate in the rumen could be increased by increasing cellulolytic bacteria activity and NDF digestibility. The present study obtained similar results with the finding that the application of Leuc. holzapfelii strain 5H4, fibrinolytic enzyme producing bacteria, increased ruminal acetate concentration through increased IVNDFD (Table 2). 


\section{Conclusions}

In conclusion, the antifungal and fibrinolytic effects on rye silage from mixed inoculant consisting of Leuconostoc holzapfelii $5 \mathrm{H} 4$ and Lactobacillus brevis 100D8 were confirmed by the results of increased IVDMD, IVNDFD, acetate, LAB, aerobic stability, and ruminal total VFA as well as decreased lactate and yeast. With the wilting process, ruminal ammonia-N was increased by low ammonia-N concentrations in silage. Additionally, aerobic stability was also increased by the wilting process, and was its highest with wilted silage treated with the mixed inoculant application.

Author Contributions: Conceptualization, S.-C.K. and S.-S.L.; methodology, S.-S.L., J.-S.C., D.H.V.P., H.-J.L., Y.-H.J., H.-T.N., and S.-C.K.; software, S.-S.L. and D.-H.K.; formal analysis, S.-S.L. and J.-S.C.; validation, S.-S.L., J.-S.C., D.H.V.P., H.-J.L., Y.-H.J., and H.-T.N.; supervision, S.-C.K. and D.-H.K.; data curation, S.-S.L., J.-S.C., D.H.V.P., H.-J.L., and Y.-H.J.; resources, S.-S.L. and S.-C.K.; writing-original draft preparation, S.-S.L. and J.-S.C.; writing-review and editing, S.-S.L., J.-S.C., D.H.V.P., D.-H.K., and S.-C.K. All authors have read and agreed to the published version of the manuscript.

Funding: This research was supported (Project No. 321083-05-1-HD040) by IPET (Korea Institute of Planning and Evaluation for Technology in Food, Agriculture, Forestry and Fisheries), and Ministry of Agriculture, Food and Rural Affairs, Republic of Korea.

Institutional Review Board Statement: The animal care and procedure to maintain cannulated heifers was approved by animal ethical committee of Gyeongsang National University, Jinju, South Korea (GNU-191011-E0050).

Informed Consent Statement: Not applicable.

Data Availability Statement: Data are available on request from the corresponding author with justifiable reason.

Conflicts of Interest: The authors declare no conflict of interest.

\section{References}

1. Puntillo, M.; Gaggiotti, M.; Oteiza, J.M.; Binetti, A.; Massera, A.; Vinderola, G. Potential of Lactic Acid Bacteria Isolated From Different Forages as Silage Inoculants for Improving Fermentation Quality and Aerobic Stability. Front. Microbiol. 2020, $11,3091$. [CrossRef] [PubMed]

2. Kim, M.J.; Kim, H.S.; Kim, S.C.; Kwak, Y.S. Complete genome sequence of Lanthionine-Producing Lactobacillus brevis Strain 100D8, generated by PacBio sequencing. Microbiol. Resour. Announc. 2018, 7, e01220-18. [CrossRef] [PubMed]

3. Liu, Q.; Lindow, S.E.; Zhang, J. Lactobacillus parafarraginis ZH 1 producing anti-yeast substances to improve the aerobic stability of silage. Anim. Sci. J. 2018, 89, 1302-1309. [CrossRef] [PubMed]

4. Paradhipta, D.H.V.; Joo, Y.H.; Lee, H.J.; Lee, S.S.; Noh, H.T.; Choi, J.S.; Kim, J.; Min, H.G.; Kim, S.C. Effects of Inoculants Producing Antifungal and Carboxylesterase Activities on Corn Silage and Its Shelf Life against Mold Contamination at Feed-Out Phase. Microorganisms 2021, 9, 558. [CrossRef] [PubMed]

5. Kang, H.C.; Park, Y.H.; Go, S.J. Growth inhibition of a phytopathogenic fungus, Colletotrichum species by acetic acid. Microbiol. Res. 2003, 158, 321-326. [CrossRef] [PubMed]

6. Yun, J.; Lee, D.G. A novel fungal killing mechanism of propionic acid. FEMS Yeast Res. 2016, 16, fow089. [CrossRef] [PubMed]

7. Desta, S.T.; Yuan, X.; Li, J.; Shao, T. Ensiling characteristics, structural and nonstructural carbohydrate composition and enzymatic digestibility of Napier grass ensiled with additives. Bioresour. Technol. 2016, 221, 447-454. [CrossRef]

8. Adesogan, A.T.; Ma, Z.X.; Romero, J.J.; Arriola, K.G. Ruminant Nutrition Symposium: Improving cell wall digestion and animal performance with fibrolytic enzymes. Anim. Sci. J. 2014, 92, 1317-1330. [CrossRef]

9. McDonald, P.; Henderson, A.R.; Heron, S.J.E. The Biochemistry of Silage, 2nd ed.; Chalcombe Publications: Marlow, UK, 1991.

10. Heo, H.Y.; Park, H.H.; Kwon, Y.U.; Kim, J.G.; Nam, J.H.; Kim, S.J.; Lee, J.K. A new high yielding rye variety 'Gogu'. Treat Crop Sci. 2004, 6, 59-66.

11. Kim, D.A.; Sung, K.I.; Kwon, C.H. Effects of sowing time and seeding rate on growth characteristics, winter survival and dry matter yield of forage rye. J. Korean Soc. Grassl. Sci. 1986, 6, 164-168.

12. Srigopalram, S.; Ilavenil, S.; Kuppusamy, P.; Yoon, Y.H.; Kim, W.H.; Choi, K.C. Silages of Rye Harvested at Different Stages: A Study on Microbial Inoculants Responses in Improving Rye Silage Fermentation Quality. J. Korean Grassl. Forage Sci. 2017, 37, 189-190. [CrossRef]

13. Kim, H.S.; Han, O.K.; Kwak, Y.S. Complete genome sequence and functional study of the fibrinolytic enzyme-producing bacterium Leuconostoc holzapfelii 5H4, a silage probiotic. J. Genom. 2017, 5, 32-35. [CrossRef] [PubMed] 
14. Paradhipta, D.H.V.; Joo, Y.H.; Lee, H.J.; Lee, S.S.; Kwak, Y.S.; Han, O.K.; Kim, D.H.; Kim, S.C. Effects of wild or mutated inoculants on rye silage and its rumen fermentation indices. Asian-Australas. J. Anim. Sci. 2020, 33, 949. [CrossRef] [PubMed]

15. AOAC. Official Method of Analysis, 18th ed.; Association of Official Analytical Chemists: Washington, DC, USA, 2005.

16. Tilley, J.M.A.; Terry, R.A. A two-stage technique for the in vitro digestion of forage crops. Grass Forage Sci. 1963, 18, $104-111$. [CrossRef]

17. Chaney, A.L.; Marbach, E.P. Modified reagents for determination of urea and ammonia. Clin. Chem. 1962, 8, 130-132. [CrossRef]

18. Adesogan, A.T.; Krueger, N.; Salawu, M.B.; Dean, D.B.; Staples, C.R. The influence of treatment with dual purpose bacterial inoculants or soluble carbohydrates on the fermentation and aerobic stability of bermudagrass. J. Dairy Sci. 2004, 87, 3407-3416. [CrossRef]

19. Adesogan, A.T.; Krueger, N.A.; Kim, S.C. A novel, wireless, automated system for measuring fermentation gas production kinetics of feeds and its application to feed characterization. Anim. Feed Sci. Technol. 2005, 123/124, 211-223. [CrossRef]

20. SAS User's Guide, 8 ed.; SAS Inst., Inc.: Cary, NC, USA, 2002.

21. McDonald, P. The Chemistry of Silage; John Wiley and Sons, Ltd.: Hoboken, NJ, USA, 1981; pp. 62-74.

22. Kim, D.H.; Lee, S.S.; Paradipta, D.H.V.; Joo, Y.H.; Lee, H.J.; Kwak, Y.S.; Han, O.K.; Kim, S.C. Effect of Homo or Heterofermentative Inoculants on Fermentation Characteristics and Aerobic Stability of Rye Silage. JALS 2017, 51, 81-89.

23. Zeng, T.; Li, X.; Guan, H.; Yang, W.; Liu, W.; Liu, J.; Du, Z.; Li, X.; Xiao, Q.; Wang, X.; et al. Dynamic microbial diversity and fermentation quality of the mixed silage of corn and soybean grown in strip intercropping system. Bioresour. Technol. 2020, 313, 123655. [CrossRef]

24. Gomes, A.L.M.; Jacovaci, F.A.; Bolson, D.C.; Nussio, L.G.; Jobim, C.C.; Daniel, J.L.P. Effects of light wilting and heterolactic inoculant on the formation of volatile organic compounds, fermentative losses and aerobic stability of oat silage. Anim. Feed Sci. Technol. 2019, 247, 194-198. [CrossRef]

25. Chen, L.; Li, P.; Gou, W.; You, M.; Cheng, Q.; Bai, S.; Cai, Y. Effects of inoculants on the fermentation characteristics and in vitro digestibility of reed canary grass (Phalaris arundinacea L.) silage on the Qinghai-Tibetan Plateau. Anim. Sci. J. 2020, 91, e13364. [CrossRef]

26. Bhat, M.K.; Hazlewood, G.P. Enzymology and other characteristics of cellulases and xylanases. In Enzymes in Farm Animal Nutrition; Bedford, M., Partridge, G., Eds.; CABI Publishing: Wallingford, UK, 2001; pp. 11-60.

27. Schimpf, U.; Hanreich, A.; Mähnert, P.; Unmack, T.; Junne, S.; Renpenning, J.; Lopez-Ulibarri, R. Improving the efficiency of large-scale biogas processes: Pectinolytic enzymes accelerate the lignocellulose degradation. J. Sustain. Energy Environ. 2013, 4, 53-60.

28. Li, F.; Ding, Z.; Ke, W.; Xu, D.; Zhang, P.; Bai, J.; Mudassar, S.; Muhammad, I.; Guo, X. Ferulic acid esterase-producing lactic acid bacteria and cellulase pretreatments of corn stalk silage at two different temperatures: Ensiling characteristics, carbohydrates composition and enzymatic saccharification. Bioresour. Technol. 2019, 282, 211-221. [CrossRef]

29. Li, J.; Yuan, X.; Dong, Z.; Mugabe, W.; Shao, T. The effects of fibrolytic enzymes, cellulolytic fungi and bacteria on the fermentation characteristics, structural carbohydrates degradation, and enzymatic conversion yields of Pennisetum sinese silage. Bioresour. Technol. 2018, 264, 123-130. [CrossRef]

30. Kung, L.; Shaver, R. Interpretation and use of silage fermentation analysis reports. Focus Forage 2001, 3, 1-5.

31. Elferink, S.O.; Driehuis, F.; Gottschal, J.; Spoelstra, S. Manipulating silage fermentation. Feed Mix. 2002, 10, 21-23.

32. Paul, M.; Donk, W.V. Chemical and enzymatic synthesis of lanthionines. Mini-Rev. Org. Chem. 2005, 2, 23-37. [CrossRef]

33. Ranjit, N.K.; Kung, L., Jr. The effect of lactobacillus buchneri, lactobacillus plantarum, or a chemical preservative on the fermentation and aerobic stability of corn silage. J. Dairy Sci. 2000, 83, 526-535. [CrossRef]

34. Holmes, B.J.; Bolsen, K.K. What's new in silage management. In Proceedings of the 15th International Silage Conference, Madison, WI, USA, 27 July 2009; pp. 1-16.

35. Nia, S.M.; Wittenberg, K.M. Effect of delayed wrapping on preservation and quality of whole crop barley forage ensiled as large bales. Can. J. Anim. Sci. 2000, 80, 145-151. [CrossRef]

36. Nishino, N.; Touno, E. Ensiling characteristics and aerobic stability of direct-cut and wilted grass silages inoculated with Lactobacillus casei or Lactobacillus buchneri. J. Sci. Food Agric. 2005, 85, 1882-1888. [CrossRef]

37. Kim, S.C.; Adesogan, A.T. Influence of ensiling temperature, simulated rainfall, and delayed sealing on fermentation characteristics and aerobic stability of corn silage. J. Dairy Sci. 2006, 89, 3122-3132. [CrossRef]

38. Hu, W.; Schmidt, R.J.; McDonell, E.E.; Klingerman, C.M.; Kung, L., Jr. The effect of Lactobacillus buchneri 40788 or Lactobacillus plantarum MTD-1 on the fermentation and aerobic stability of corn silages ensiled at two dry matter contents. J. Dairy Sci. 2009, 92, 3907-3914. [CrossRef]

39. Adesogan, A.T. Improving forage quality and animal performance with fibrolytic enzymes. In Proceedings of the 2005 Florida Ruminant Nutrition Symposium, 16th Annual Meeting, Gainesville, FL, USA, 1 February 2005; pp. 91-109.

40. Morgan, C.A.; Edwards, R.A.; McDonald, P. Intake and metabolism studies with fresh and wilted silages. J. Agric. Sci. 1980, 94, 287. [CrossRef]

41. Hristov, A.; Broderick, G. Ruminal microbial protein synthesis in cows fed alfalfa silage, alfalfa hay or corn silage and fitted with only ruminal cannulae. In Proceedings of the Society of Nutrition Physiology: Abstracts of Communications, VIII International Symposium on Ruminant Physiology, Hessen, Germany, 25 September 1994. 
42. Hristov, A.N.; Ropp, J.K. Effect of dietary carbohydrate composition and availability on utilization of ruminal ammonia nitrogen for milk protein synthesis in dairy cows. J. Dairy Sci. 2003, 86, 2416-2427. [CrossRef]

43. Charmley, E.; Veira, D. Inhibition of proteolysis at harvest using heat in alfalfa silages: Effects on silage composition and digestion by sheep. J. Anim. Sci. 1990, 68, 758-766. [CrossRef] [PubMed]

44. Silva, L.S.; Bezerra, L.R.; Silva, A.M.D.A.; Carneiro, H.; Moreira, M.N.; Oliveira, R.L. In vitro degradation and gas production of glycerin generated in the biodiesel production chain. Acta Sci. Anim. Sci. 2015, 37, 265-272. [CrossRef]

45. Wan, J.C.; Xie, K.Y.; Wang, Y.X.; Liu, L.; Yu, Z.; Wang, B. Effects of wilting and additives on the ensiling quality and in vitro rumen fermentation characteristics of sudangrass silage. Anim. Biosci. 2020, 34, 56-65. [CrossRef]

46. Meller, R.A.; Wenner, B.A.; Ashworth, J.; Gehman, A.M.; Lakritz, J.; Firkins, J.L. Potential roles of nitrate and live yeast culture in suppressing methane emission and influencing ruminal fermentation, digestibility, and milk production in lactating Jersey cows. J. Dairy Sci. 2019, 102, 6144-6156. [CrossRef] 